\title{
US researchers losing battle to hide their data from prying eyes
}

[WASHINGTON] Scientists' representatives are losing a fight to protect US researchers from rules which, they say, could wreak havoc in laboratories by allowing outside parties to examine federally funded data at any time - perhaps even before publication under freedom of information laws.

Defeat in a crucial vote of the House Appropriations Committee, followed by the death on 15 July of George Brown (Democrat, California), the senior Democrat on the House Science Committee and a vigorous opponent of the rules, leaves the way open for them to go into force in October, say science lobbyists.

Bruce Alberts, the president of the National Academy of Sciences, and Harold Varmus, director of the National Institutes of Health, both testified in Congress last week that the proposed rules would damage the scientific process and open researchers in controversial fields to endless harassment by special-interest groups.

"There are pitfalls in unrestrained openness," Varmus warned. These included "unwarranted violations of privacy, the

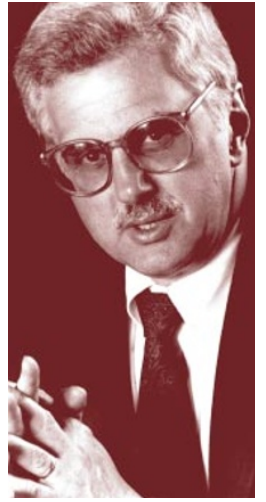

potential harassment of scientific investigators, and the chilling effect that such scrutiny could have on the free exchange of ideas".

The rules were initially proposed by Senator Richard Shelby (Republican, Alabama), and quietly passed into law last October as part of a huge budget bill. They would allow interAlberts: new rules ested parties to request "inviteharassment". data from all government-funded scientists by issuing a request under the Freedom of Information Act (FOIA), the legislation intended to prevent the federal government keeping secrets from the public.

The law requires the White House Office of Management and Budget (OMB) to draw up rules for the application of FOIA to university research (see Nature 397, 459; 1999). But many believe that the Shelby provision is

\section{Computer upgrade for Canadian science}

[MONTREAL] Canadian scientists keen to gain access to high-performance computing facilities will benefit from an award of Can\$23 million (US\$15.5 million) from the Canada Foundation for Innovation (CFI).

The new money, combined with expected contributions from other sources, means that new research facilities worth more than Can\$70 million will be available for research in areas as diverse as climate prediction, engineering, industrial design, medicine, astronomy and chemistry.

Canada's CaNet 3 facilities, offering stateof-the-art Internet access, will make possible a grid of computational resources that will encourage close collaboration between research institutions across Canada. That should help to "preserve one of our country's most important resources, its intellectual capital," says David Strangway, CFI's president and chief executive officer.

The awards for high-performance computing facilities were among a total investment by the CFI of Can\$226 million to support 122 infrastructure projects in 51 universities, colleges, hospitals and nonprofit research institutions.

According to Strangway, the money will be joined by an additional Can $\$ 339$ million from partners in the public, private and voluntary sectors. Since August 1998, awards by the CFI, a non-profit corporation established by the federal government in 1997, have totalled Can\$426 million. Contributions from other partners have resulted in a total capital investment of more than Can\$1 billion in research facilities.

The national network of shared computational research facilities will be created by a new Canadian initiative called C3.ca, an umbrella organization set up in March. Brian Unger, president of C3.ca, says CFI's support "towards a world-class infrastructure will enable us to more successfully compete at an international level".

By using parallel architecture, the network will allow some of the largest computers in the world to operate in unison for research not only in science and engineering, but also in finance, business and the arts.

Six universities and regional consortia, all members of C3.ca, were approved for CFI funding. They will establish facilities for computation and visualization, including about a dozen parallel shared memory and vector systems for advanced computing, along with six new multimedia visualization centres. primarily intended to let industry groups challenge university scientists researching the effects of pollution, tobacco or firearms.

"This actually invites harassment of scientists by those who don't like what the scientist is doing," Alberts told a 15 July hearing of the House subcommittee on government management, information and technology.

Pro-business groups and a former Republican OMB director testified against legislation proposed by Brown that would have overturned the Shelby provision. Alberts and Varmus supported the Brown legislation. But Brown, who had been ill since contracting an infection during heart surgery in May, was unable to testify, and died shortly after the hearing (see pages 295 and 305).

Although Stephen Horn (Republican, California), chairman of the government management subcommittee, was non-committal, the rest of his subcommittee divided along party lines, with the Republican majority opposing the Brown legislation.

Two days earlier, scientists' efforts to block the Shelby regulation had suffered a serious setback, when the powerful Appropriations Committee voted 33-25 against an amendment put forward by James Walsh (Republican, New York) and David Price (Democrat, North Carolina) to suspend its implementation for a year.

Science lobbyists say that the amendment fell after intense lobbying by groups including the National Rifle Association and the US Chamber of Commerce, which sees Shelby's seemingly arcane proposal as a key means of rolling back government regulation.

According to a circular issued by the chamber in March, the regulation "will do more for regulatory reform than all the legislation passed in the last ten years" if it is "implemented properly". Industry groups believe that the rule will enable them to challenge scientific studies that agencies, such as the Environmental Protection Agency, use to justify new regulations.

The OMB is seeking to lessen the impact of the provision when it publishes the detailed rule under which it will be implemented. In a second draft, due to be released for public comment shortly, it seeks to introduce a definition of scientific data that will exclude personal medical data and commercial proprietary information.

But opponents of the regulation say that such distinctions may not stand up in court, where the Freedom of Information Act could be interpreted as requiring all information to be released. "The Shelby amendment is fatally flawed," says Alberts. ColinMacilwain 